\title{
A Delayed Death due to an Accidental Bullet Brain Injury Initially Mistaken for a Blunt Trauma The Importance of Good Practice in Forensic Medicine
}

\author{
Massimo Lancia ${ }^{5 *}$, Giacomo Gualtieri ${ }^{2}$, Sara Gioia ${ }^{3}$, Alfonso Cerase ${ }^{4}$, Matteo Benvenuti ${ }^{1}$ and Mario Gabbrielli ${ }^{6}$ \\ ${ }^{1}$ MD, Forensic Medicine, Department of Medical Sciences, Surgical and Neurosciences, Hospital Santa Maria alle Scotte, University of Siena, Italy \\ ${ }^{2}$ MD, Forensic Medicine, Department of Medical Sciences, Surgical and Neurosciences, Hospital Santa Maria alle Scotte, University of Siena, Italy \\ ${ }^{3} M D$, Forensic Medicine, Section of Legal Medicine, University of Perugia, Italy
}

${ }^{4}$ MD, Unit of Neuroimaging and Neurointervention, Department of Neurological and Sensorineural Sciences, Hospital Santa Maria alle Scotte, University of Siena, Italy

${ }^{5}$ Associated professor, Forensic Medicine, Section of Legal Medicine, University of Perugia, Italy

${ }^{6}$ Full professor, Coordinator of Section of Legal Medicine, Department of Medical Sciences, Surgical and Neurosciences, Hospital Santa Maria alle Scotte, University of Siena, Italy

Submission: January 29, 2018; Published: February 02, 2018

*Corresponding author: Massimo Lancia, Associated Professor, Forensic Medicine, Section of Legal Medicine, University of Perugia, P.le Severi 1, Perugia, 06121, Italy, Tel: 0755858174; Email: dr.massimolancia@gmail.com

\begin{abstract}
A seventy-one-year-old woman was found to the ground of her bedroom, in a pool of blood; she was immediately rescued and taken to the Emergency Room where she appeared alert and aware. She explained to doctor that she had fallen spontaneously, wounding so her head. The lady, after this aware brief interaction, soon died. Based on woman's statements, the death was classified as accidental. However, the prosecutor ordered a forensic evaluation, as required by the recommendations of the Committee of European Union ministers, and found the lady had a brain injury due to gunshot. After long investigation the truth came out: while cleaning his gun, a man exploded unintentionally a shot towards a building near his home, killing so his neighbor. Due to the unexpected and sudden hit of the head by the bullet, the women did not understand what happened and reported only the fall misleading the emergency responders to the incidental nature of the trauma. This case report emphasizes the importance to performe the autopsy findings in all cases of death that could have an unnatural cause, as recommended by the international autopsy Judicial guidelines.
\end{abstract}

Keywords: Stray Bullet; Firearms; Brain Injury; Guidelines; Unnatural Death; Death Investigation

\section{Introduction}

There is a global increase in unintended firearm injuries from Europe to America, UK and Asia [1]. In some countries like Pakistan [2], Iran [3] and India [4] public uprising, protests and aggressive mobs are commonly controlled by using force and aerial firing is a well known tool used by administrative bodies to disperse the aggressive mobs. In general numerous factors play a role in the overall incidence of stray bullet injuries such as an undue and inappropriate use of guns, an undue public exposure of weapons or an inadequate maintenance and custody [5]. In some countries there is an additional factor due to tradition of celebrating the marriage ceremonies or the birth of a male child by way of opening aerial fires $[2,6,7]$. Wintemute et al. [8] carried out a survey in USA that showed that 317 persons were injured by stray bullets in a year, of whom 65 (20.5\%) died. The issue of stray bullet injuries is very important and widespread, but very often overlooked and so poorly studied. The case object of our report fits into this perspective.

\section{Case Report}

A 71-year-old woman was found lying on the floor in her bedroom, near the window. She was supine, with the head turned to the left in a pool of blood. Her relatives immediately alerted the emergency staff. The woman was conscious and responsive, and stated to her relatives and the emergency staff 
that she had fallen to the ground and beaten her head. After all she proved to be cooperative; her pupils were isocyclic and normally reactive. Yet, she had two severely bleeding wounds on her forehead. In a matter of time she died with the diagnosis of hemorrhagic shock due to dual wound to the forehead. The doctors suspected that she might have fallen hitting her head, because of an illness or a stumble. After the entire woman suffered from frequent dizziness and in the previous months she already injured herself due to this problem. Classifying the death was accidental seemed the most logical diagnosis. Yet, not everyone shared the same opinion and the Prosecutor ordered a routine medico-legal evaluation. Just 24 hours later a forensic examination was performed revealing an unexpected situation.

The External study of the body showed two skin and bone injuries in the right and left fronto-temporo-parietal regions, while a pre-autopsy skull X-rays highlighted multiple bilateral fronto-temporal fractures and bilateral frontal small bone fragments and continuous solutions. But the real clue came from the internal examination. A U-shaped notch with the concavity facing upwards, with black bony edges clearly emerged in the left frontal region of the skull. Such lesion was fully compatible with the entrance hole of a single bullet, $0.9 \mathrm{~cm}$ of diameter. Computed tomography and magnetic resonance imaging of the brain (Figure 1) confirmed the evidence of multiple bony fragments in both the left frontal lobe (mainly in the basal portion) and, in a lesser number, in the contra lateral one, as well as subarachnoid, intra-axial, and intraventricular hemorrhage, in both the frontal lobes with predominance in the left one. The gross examination of the brain showed a wide subarachnoid hemorrhage at the frontal and parietal lobes. In the apical part of the left frontal lobe, there was an area of laceration with a depth of about $4 \mathrm{~cm}$ and the proximal cerebral tissue had multiple hemorrhagic dotting. The initial hypothesis of an accidental fall was feasible anymore. Only a gunshot could have caused that wound In fact further investigation carried out by the Police led to the discovery of a bullet hole in the shutter even if the buller was never found. But, after an extensive inquiry, the truth came out. The woman's neighbor had fired an unintentional shot while cleaning his gun. The unliky woman just happened to be on the wrong spot at the wrong time.

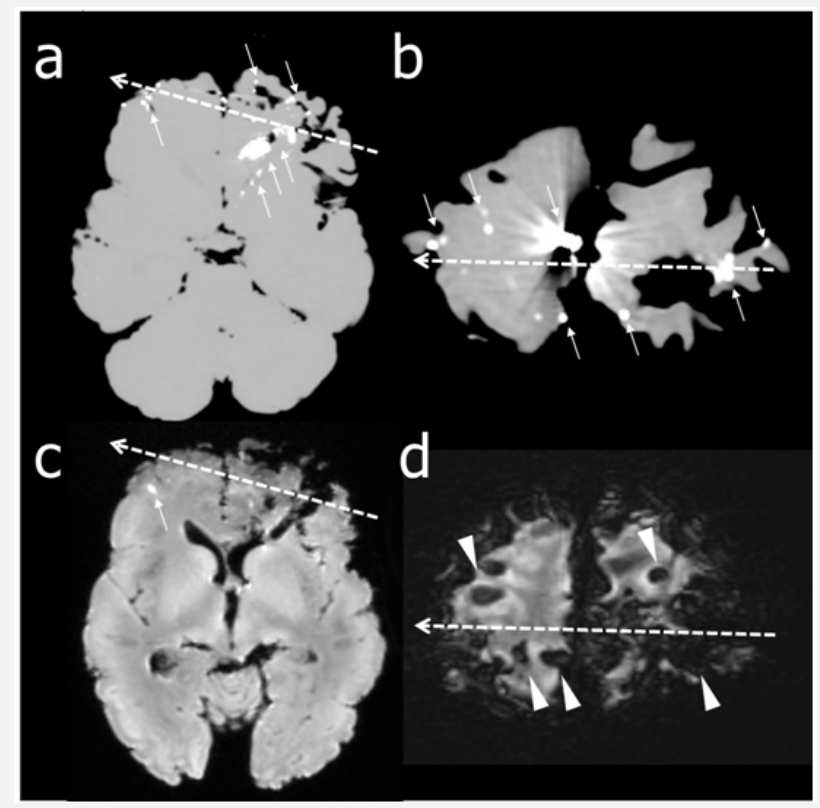

Figure1.

\section{Discussion and Conclusion}

Notably, nowadays postmortem neuroradiology is a well established advance and help in forensic cranio-encephalic pathology [9]. In fact, in the case presented herein, the association of autopsy with postmortem skull X-rays and brain CT and MRI showed that the cause of death was due to a gunshot wound from a single bullet. Thus allowed to exclude the initial hypothesis of an accidental death. It was a single bullet, of the approximate diameter of about $0.9 \mathrm{~cm}$, which hit the woman at the left frontal region. The shot direction was from left to right and with an almost horizontal course, i.e. slightly from bottom to top. The projectile entered the cranium and the brain surface of the frontal lobes and passed just above the base of the skull. Then, it left at the right frontal region, after having provoked a complex fracture of the cranial bones of the plateau. The injury didn't cause an immediate death; on the contrary, after the shot, the woman was conscious and responsive and had interaction with relatives and doctors.

The passage of the bullet did not bring an immediate death of the subject, since there was only a small area of loss of cerebral 
substance in the lower face of the left frontal lobe. Anyway it was not susceptible to any medical and surgical treatment, and it prevented the medical staff from saving the victim's life. Death occurred only after a short time, because of cerebral hemorrhage. Brain functional anatomy explains the fact that the subject, once hit by the bullet, was able to talk with the people who came to aid her. Actually, after the famous case of Phineas Cage $[10,11]$, many cases of non-lethal brain injuries have been reported in the literature [12-14]. The data in the literature show the need to adopt stricter rules on the possession and use of firearms. Particularly in those countries where legislation allows with relative ease to own a firearm, we should adopt more stringent measures governing the use and custody. Last but not least, this seemingly simple case emphasizes the importance to perform the autopsy findings in all cases of death that could have an unnatural cause, violent or in suspicious circumstances, as recommended by the international autopsy judicial guidelines [15-17].

\section{References}

1. Persad IJ, Reddy RS, Sunders MA, Patel J (2005) Gunshot injuries to the extremities: experience of a UK trauma centre. Injury 36(3): 407-411.

2. Malik AM, Alkadi A, Talpur KAH, Qureshi JN (2013) the incidence, pattern and outcome of stray bullet injuries: a growing challenge for surgeons. Pak J Med Sci 29(5): 1178-1181.

3. Ali SA, Tahir SM, Makhdoom A, Shaikh AR, Siddique AJ (2015) Aerial firing and stray bullet injuries: a rising tide. Iran Red Crescent Med J 17(4): e26179.

4. Wani AA, Ramzan AU, Shoib Y, Malik NK, Nizami FA, et al. (2011) Stray bullet: an accidental killer during riot control. Surg Neurol Int 2: 122.

5. Lancia M, Rosati V, Gioia S, Conforti F, Suadoni F (2014) An unusual case of unintentional firearm death of a 3-year-old child. Am J Forensic Med Pathol 35(3): 178-180.

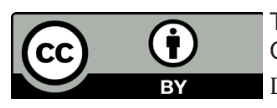

This work is licensed under Creative Commons Attribution 4.0 License

DOI : 10.19080/JFSCI.2018.07.555714
6. Ozdemir M, Unlu A (2009) Gunshot injuries due to celebratory gun shooting. Turkish Neurosurgery 19(1): 73-76.

7. Incorvaia AN, Poilos DM, Jones RN, Tschirhart JM (2007) Can a falling bullet be lethal at terminal velocity? Cardiac injury caused by a celebratory bullet. Ann Thoracic Surg 83(1): 283-284.

8. Wintemute GJ, Claire BE, McHenry V, Wright MA (2012) Epidemiology and clinical aspects of stray bullet shootings in the United States. J Trauma Acute Care Surg 73(1): 215-223.

9. Ruder TD, Thali MJ, Hatch GM (2014) Essentials of forensic post-mortem MR imaging in adults. Br J Radiol 87(1036): 20130567.

10. Ratiu P, Talos IF (2004) The Tale of Phineas Gage, Digitally Remastered. N Engl J Med 351: e21.

11. Van Horn JD, Irimia A, Torgerson CM, Chambers MC, Kikinis R, et al. (2012) Mapping connectivity damage in the case of Phineas Gage. PLoS One 7(5): e37454.

12. Martucciello G, Tripodi R (2012) A stray bullet in the brain. Lancet 379(9812): e19.

13. Hussain M, Bari E (2011) Intracerebral migration of stray bullet leading to sudden and fatal worsening. J Coll Physicians Surg Pak 21(3): 182-183.

14. Qureshi AU, Akhtar S, Gondal KM (2010) Stray bullet in inferior vena cava. J Coll Physicians Surg Pak 20(6): 414-415.

15. Recommendation $n^{\circ} \mathrm{R}$ (99) 3 of the Committee of Ministers to Member States of European Union relating to standardize rules for judicial autopsy.

16. Kenji Ishihara, Hisako Takeichi, Hirotaro Iwase (2014) The JSLM 'Guidelines for Notification of Unnatural Death': Comparison with the systems of reporting death in other countries. Legal Medicine 16(2): 110-113.

17. Carpenter B, Tait G, Barnes M, Adkins G, Naylor C, et al. (2009) Increasing the information available to coroners: the effect on autopsy decision-making. Med Sci Law 49(2): 101-108.

\section{Your next submission with Juniper Publishers} will reach you the below assets

- Quality Editorial service

- Swift Peer Review

- Reprints availability

- E-prints Service

- Manuscript Podcast for convenient understanding

- Global attainment for your research

- Manuscript accessibility in different formats

( Pdf, E-pub, Full Text, Audio)

- Unceasing customer service

Track the below URL for one-step submission https://juniperpublishers.com/online-submission.php 